\title{
ANALISIS KESALAHAN SISWA DALAM MENYELESAIKAN SOAL CERITA BANGUN DATAR DI SMP DAERAH MALANG
}

\author{
(Analysis of Student Errors in Completing the Problem in Junior High School \\ Malang)
}

\author{
Rinda Azmi Saputri \\ Program Studi Pendidikan Matematika \\ Universitas Muhammadiyah Banjarmasin \\ Email: rinda.azmi.saputri@umbjm.ac.id
}

\begin{abstract}
ABSTRAK
Penelitian ini bertujuan untuk menganalisis kesulitan peserta didik pada soal cerita bangun datar ditinjau dari beberapa kesalahan fakta, kesalahan operasi, kesalahan konsep dan kesalahan prinsip. Subjek penelitian ini tiga orang siswa kelas VIIIB di SMP Daerah Malang yang diambil berdasarkan tingkat kemampuan matematikanya tinggi, rendah dan sedang atas saran dari guru yang mana komunikasi siswa tersebut baik. Pendekatan penelitian yang digunakan yaitu kualitatif, adapun jenis penelitian ini yaitu deskriptif. Analisis data yang digunakan adalah analisis dokumen. Hasil penelitian menunjukkan Siswa kemampuan rendah melakukan kesalahan fakta pada soal no.1, kesalahan fakta dan prinsip pada no.2, serta kesalahan fakta dan prinsip pada soal no.3. Siswa kemampuan sedang melakukan kesalahan fakta pada soal no.2 dan kesalahan prinsip pada soal no.3. Siswa kemampuan tinggi melakukan kesalahan fakta dan prinsip pada soal no.2 serta kesalahan fakta pada soal no.3.
\end{abstract}

Kata kunci : kesulitan, soal cerita, bangun datar

\section{ABSTRACT}

This study aims to analyze the difficulties of students in math word problems two dimentional figure fact errors, operating errors, conceptual errors and principle errors. The subjects of this study were three class VIIIB students at the Middle School in Malang which were taken based on their high, low and moderate mathematical abilities on the advice of the teacher where the students' communication was good. The research approach used is qualitative, while the type of research is descriptive. Analysis of the data used is document analysis. The results of the study showed that low ability students made a mistake in fact in question no.1, errors in facts and principles at no.2, as well as errors in facts and principles in question no.3. Ability students are making mistakes in the questions no.2 and principle errors in question no.3. High-ability students make mistakes in facts and principles in question No. 2 and error facts about story problems two dimentional figure.

Keywords : difficulties, math word problems, two dimentional figure fact 


\section{PENDAHULUAN}

Pendidik atau guru dituntut untuk selalu meningkatkan diri baik dalam pengetahuan matematika maupun pengelolaan proses belajar mengajar. Hal ini dalam upaya untuk meningkatkan mutu pendidikan khususnya mata pelajaran matematika. Ini dimaksudkan agar para peserta didik dapat mempelajari matematika dengan baik dan benar sehingga mereka mampu mengikuti perkembangan ilmu pengetahuan dan teknologi serta dapat menerapkannya dalam kehidupan sehari-hari.

Keanekaragaman kemampuan intelektual peserta didik khususnya dalam matematika di SMP sangat bervariasi. Kemampuan ini menyangkut kemampuan untuk: mengingat kembali, memahami, menginterpretasi informasi, memahami makna simbol dan memanipulasinya, mengabstraksi, menggeneralisasi, menalar, memecahkan masalah, dan masih banyak lagi. Sikap dan perangai peserta didik pun beraneka ragam, baik dalam menanggapi pembelajaran pada umumnya maupun matematika pada khususnya (Gangga, 2013).

Menurut penelitian Rudtin (2013) hasil tes kelas VIII di SMPN 7 Palu yang diikuti oleh 29 orang siswa untuk mengidentifikasi masalah yang berkaitan dengan soal cerita pada materi keliling dan luas persegi panjang menunjukkan 19 orang siswa tidak menjawab soal tes yang diberikan. Hal ini disebabkan mereka tidak memahami maksud dari soal. Berdasarkan hasil wawancara Fatmawati, et.al (2014) dengan seorang guru matematika di SMK Muhammadiyah 1 Sragen siswa mampu menyelesaikan soal dengan perhitungan maupun menyelesaikan soal yang hampir sama dicontohkan oleh guru, namun akan kesulitan jika soal tersebut diubah menjadi bentuk soal yang lain dan jika dibuat dalam soal cerita.

Penguasaan siswa sekolah menengah dalam objek geometri yang bersifat abstrak ternyata di lapangan tidak seperti yang diharapkan. Hal ini sesuai dengan penelitian yang menyimpulkan bahwa penguasaan siswa terhadap geometri masih rendah (Ozerem, 2012; Herlambang, 2013; Sukayasa, 2009). Hasil observasi dan wawancara Ifanali (2014) dengan guru mata pelajaran matematika kelas VII SMP Negeri 13 Palu diperoleh informasi bahwa masih banyak siswa yang mengalami kesulitan dalam menyelesaikan soal cerita tentang pecahan.
Kesalahan yang dilakukan siswa dalam menyelesaikan soal geometri dikarenakan siswa melakukan kesalahan konsep, melakukan kesalahan operasi, dan melakukan kesalahan analisis serta tidak mampu mengingat kembali konsep atau operasi yang berkaitan dengan materi geometri yang telah dipelajari sebelumnya (Roskawati, et.al, 2015).

Berdasarkan pengamatan awal penelitian Musriniyatik, et.al (2014) melalui tes awal pertama dengan materi prasyarat tentang mengidentifikasi bangun datar yang terdiri dari segitiga, persegi, persegi panjang, jajar genjang, belah ketupat, layang-layang dan trapesium diperoleh informasi bahwa rata-rata nilai tes awal adalah 68,71 dan $41,94 \%$ siswa mendapat nilai lebih dari atau sama dengan kriteria ketuntasan minimum, yaitu 75 . Beberapa kesulitan yang dihadapi beberapa siswa adalah: 1) tidak paham bagaimana cara memisahkan bangun yang berupa gabungan dari segitiga, persegi, persegipanjang, dan trapesium menjadi bagian-bagiannya; 2) tidak tahu (lupa) rumus untuk menghitung luas bangun datar; dan 3) tahu rumus tetapi salah prosedur operasi hitung. Mengingat pentingnya peranan materi bangun datar dalam matematika dan dalam kehidupan sehari-hari, menurut penulis keterampilan menyelesaikan masalah bangun datar perlu ditekankan dengan diawali kegiatan memahamkan siswa tentang materi bangun datar.

Soal cerita penting untuk diberikan kepada siswa guna melatih siswa dalam menyelesaikan masalah. Namun sayangnya, banyak siswa yang melakukan kesalahan dalam menyelesaikan soal cerita. Kesalahan-kesalahan dilakukan siswa dalam menyelesaikan soal cerita yaitu kesalahan memahami soal, kesalahan melakukan komputasi, dan kesalahan menginterpretasikan jawaban model matematika. Soal cerita matematika merupakan soal yang terkait dengan kehidupan sehari-hari untuk dicari penyelesaiannya menggunakan kalimat matematika yang memuat bilangan, operasi hitung, dan relasi $(=,<,>, \leq, \geq)$ (Rahardjo \& Astuti, 2011).

Kesalahan timbul akibat adanya kesulitan siswa dalam belajar. Seorang anak yang mengalami kesulitan dalam belajarnya akan menunjukkan ciri-ciri dari adanya masalah yang dialami, seperti yang dituliskan oleh Mappaita Muhkal (dalam Rahim, 2013) sebagai berikut: (a) menunjukkan hasil belajar yang lebih rendah (dibawah nilai rata-rata) yang dicapai oleh 
kelompoknya; (b) hasil yang dicapai tidak seimbang dengan usaha yang dilakukannya; (c) lambat dalam melaksanakan tugas-tugas belajarnya; (d) menunjukkan sikap-sikap yang kurang wajar; (e) menunjukkan tingkah laku yang berkelainan dan; (f) menunjukkan gejala emosional yang kurang wajar.

Salah satu strategi untuk mengatasi kesalahan-kesalahan yang dilakukan siswa dalam menyelesaikan soal cerita yaitu bisa dengan menerapkan strategi pemecahan masalah yang disusun oleh Polya. Strategi pemecahan masalah yang disusun oleh Polya yaitu memahami masalah, membuat rencana penyelesaian, menyelesaikan rencana penyelesaian, dan memeriksa kembali. Adinawan \& Sugijono (2008) menyarankan langkah-langkah yang dilakukan untuk menyelesaikan soal matematika yang berbentuk cerita, yaitu sebagai berikut: a) membuat diagram, khususnya soal matematika yang berhubungan dengan geometri; b) mengubah kalimat soal menjadi kalimat matematika, dan c) menyelesaikan kalimat matematika.

Menurut Cooney (1975), terdapat empat jenis yang dihubungkan dengan objek dasar matematika, yaitu: a) kesalahan fakta; b) kesalahan konsep; c) kesalahan operasi; d) kesalahan prinsip. Kesalahan fakta adalah kekeliruan dalam menuliskan konvensi-konvensi yang dinyatakan dengan simbol-simbol matematika. Contoh: kesalahan dalam mengubah permasalahan ke dalam bentuk model matematika, kesalahan dalam menginterpretasikan hasil yang didapatkan dan kesalahan dalam menuliskan simbol-simbol matematika. Kesalahan konsep adalah kekeliruan dalam menggolongkan atau mengklasifikasikan sekumpulan objek. Konsep yang dimaksud dalam matematika dapat berupa definisi. Contoh: kesalahan dalam menggolongkan suatu relasi, apakah merupakan suatu fungsi atau tidak. Kesalahan operasi adalah kekeliruan dalam pengerjaan hitung, pengerjaan aljabar, dan pengerjaan matematika yang lain. Contoh: kesalahan dalam menjumlahkan, mengurangkan, dan kesalahan dalam operasi matematika lainnya. Kesalahan prinsip adalah kekeliruan dalam mengaitkan beberapa fakta atau beberapa konsep. Contoh: kesalahan dalam menggunakan rumus ataupun teorema serta kesalahan dalam menggunakan prinsip-prinsip sebelumnya.

Masalah merupakan sesuatu yang pasti ditemui dalam kehidupan yang harus dipecahkan, bukan dihindari, karena dengan menghindarinya di samping akan muncul lagi masalah yang sama atau serupa juga memungkinkan menambah banyak masalah yang semakin sulit dipecahkan. Kesalahan-kesalahan yang dihadapi siswa itu perlu ditemukan dan dipastikan sumbernya, sehingga guru bisa memperbaiki kesalahankesalahan tersebut dan tidak terulang lagi. Dengan demikian penelitian ini membahas tentang kesalahan yang dialami siswa dalam menyelesaikan soal cerita bangun datar.

\section{METODE PENELITIAN}

Jenis penelitian yang digunakan adalah penelitian deskriptif dengan pendekatan kualitatif. Dalam penelitian ini, instrumen utama dalam pengumpulan data adalah peneliti sendiri. Hal ini dikarenakan peneliti langsung berhubungan dengan subjek penelitian sehingga fokus penelitian menjadi jelas, dan diharapkan dapat melengkapi data, serta dalam membandingkan dengan data yang telah ditemukan melalui observasi dan wawancara (Sugiyono, 2013).

Subjek penelitian ini yaitu siswa kelas VIIIB di SMP Islam Hasanuddin Malang. Subjek yang diambil hanya tiga orang. Pemilihan subjek wawancara berdasarkan analisa tes kemampuan matematika siswa menyelesaikan luas dan keliling bangun datar dalam bentuk soal cerita dengan kategori tinggi, sedang, dan rendah, serta atas saran guru dengan komunikasi yang baik.

Instrumen penelitian berupa transkrip wawancara dan dokumentasi berupa lembar tes siswa. Adapun wawancara yang digunakan yaitu wawancara terbuka. Materi yang diambil yaitu tentang luas dan keliling bangun dalam bentuk soal cerita yang sudah dipelajari di kelas VII. Soal tersebut diambil dari soal UN tahun ajaran 2014/2015 yang terdiri dari tiga soal. Adapun koefisien korelasi soal pertama yaitu 0.95 pada kategori sangat tinggi, koefisien korelasi soal kedua yaitu 0.73 kategori tinggi, dan koefisien korelasi soal ketiga yaitu 0.79 kategori tinggi, dengan koefisien reliabilitas 0.76 kategori tinggi. Semakin tinggi kriteria koefisien korelas, maka semakin valid. Sehingga, dapat disimpulkan ketiga soal yang diujikan valid dan reliabel.

Langkah-langkah yang dilakukan untuk menganalisis data yaitu menyusun data secara sistematis dan menjabarkannya, memilih dan memilah data yang penting, serta membuat kesimpulan. Analisis penelitian dilakukan dengan cara menganalisis lembar jawaban siswa dan 
transkrip wawancara yang diperoleh kemudian dianalisis secara khusus untuk mengetahui kesalahan-kesalahan yang dialami siswa dalam menyelesaikan soal cerita bangun datar. Hasil analisis lembar jawaban siswa kemudian dikombinasikan dengan hasil wawancara siswa.

\section{HASIL DAN PEMBAHASAN}

Berikut penjabaran dari ketiga siswa terkait dengan kesalahan-kesalahan yang dilakukan terkait soal cerita bangun datar berdasarkan hasil jawaban siswa dan wawancara siswa:

VSB (siswa kemampuan rendah)

Ada 4 jenis kesalahan siswa dalam menyelesaikan soal, yaitu kesalahan fakta, konsep, operasi dan prinsip. Soal no.1 VSB melakukan kesalahan fakta. Berikut hasil jawaban siswa terkait soal no.1

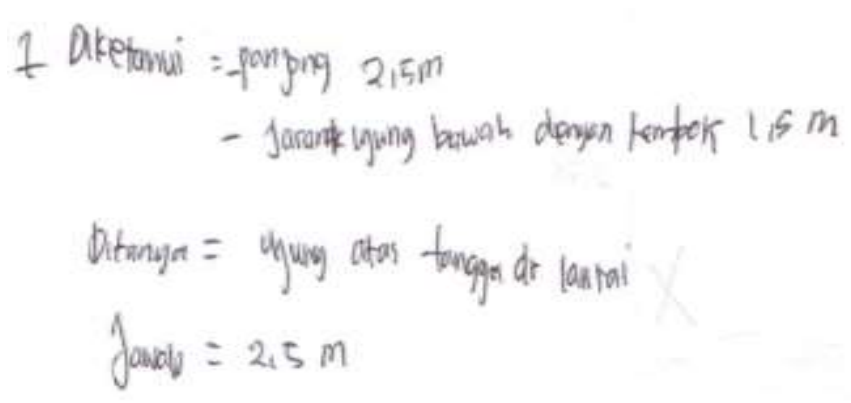

Gambar 1. VSB menuliskan apa yang diketahui dan ditanya dari soal no. 1

Hasil wawancara siswa menunjukkan bahwa siswa sudah dapat menyebutkan apa yang diketahui dan ditanya dengan tepat. Berikut hasil wawancara siswa:

Peneliti

: "Dari soal ini dapatkah kamu menyebutkan apa yang diketahui dan ditanyakan?"

Siswa : :Dapat, yang diketahui panjang tangga $2,5 \mathrm{~m}$, jarak ujung bawah tangga dengan tembok $1,5 \mathrm{~m}$, ditanya tinggi ujung atas tangga dari lantai"

Namun, siswa sebenarnya belum memahami soal secara keseluruhan, siswa masih belum tepat ketika diminta menggambarkan apa yang diketahui. Berikut jawaban siswa ketika diminta untuk menggambarkan apa yang diketahui dan ditanyakan:

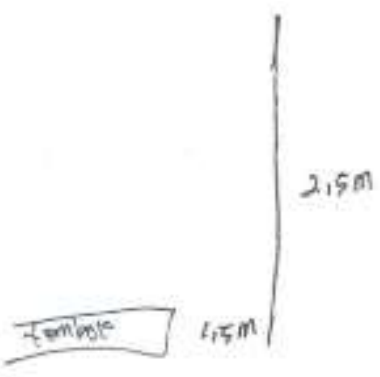

Gambar 2. VSB membuat gambar dari apa yang diketahui dari soal no. 1

Pada gambar di atas menunjukkan VSB melakukan kesalahan fakta, siswa masih belum bisa membuat apa yang diketahui ke gambar yang dibuatnya. Siswa menuliskan panjang tangga di tinggi tembok, sehingga berpengaruh pada jawaban siswa, karena siswa mengangggap 2,5m adalah tinggi tembok, sehingga siswa tidak mencari soal yang ditanyakan lagi.

Soal no.2 VSB melakukan kesalahan fakta dan prinsip. Berikut hasil jawaban siswa terkait soal no.2 :

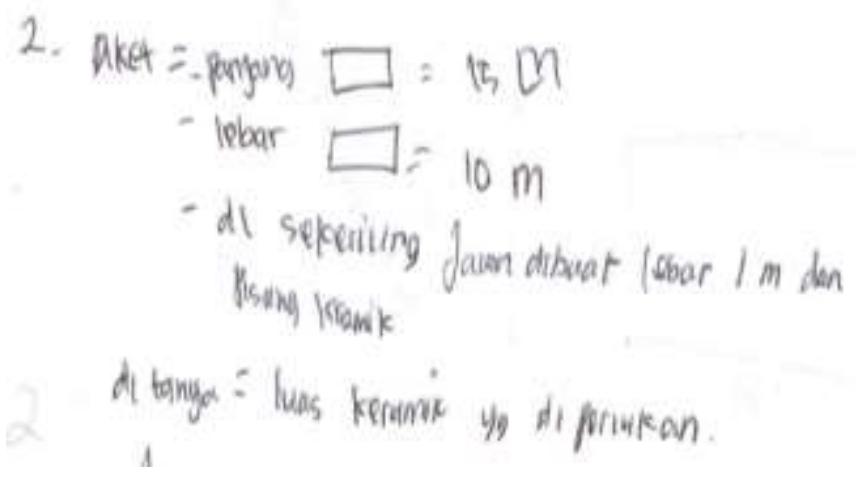

Gambar 3. VSB menuliskan apa yang diketahui dan ditanya dari soal no.2

Hasil wawancara siswa menunjukkan bahwa siswa sudah dapat menyebutkan apa yang diketahui dan ditanya dengan tepat. Berikut hasil wawancara siswa:

Peneliti

: "Dari soal ini dapatkah kamu menyebutkan apa yang diketahui dan ditanyakan?"

Siswa : : "lya, yang diketahui panjang persegi panjang $15 \mathrm{~m}$, lebar 
persegi panjang $10 \mathrm{~m}$, di sekeliling jalan dibuat lebar $1 \mathrm{~m}$ dan dipasang keramik, ditanya luas keramik $n$ dibuat yang diperlukan"

Namun, siswa sebenarnya belum memahami soal secara keseluruhan, siswa masih belum tepat ketika diminta menggambarkan apa yang diketahui. Berikut jawaban siswa ketika diminta untuk menggambarkan apa yang diketahui dan ditanyakan:

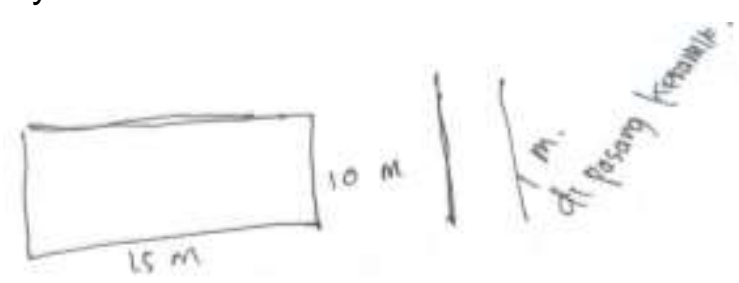

Gambar 4. VSB membuat gambar dari apa yang diketahui dari soal no.2

Siswa masih belum tepat menuliskan apa yang diketahui dan ditanyakan pada gambar yang dibuatnya. Di sini siswa melakukan kesalahan fakta. Siswa belum tepat secara keseluruhan mengubah apa yang diketahui ke gambar yang dibuatnya. Siswa sudah tepat menggambarkan kolam renang berbentuk persegi dengan panjang $15 \mathrm{~m}$ dan lebar $10 \mathrm{~m}$, namun siswa masih belum memahami di sekeliling kolam dibuat jalan dengan lebar $1 \mathrm{~m}$, siswa menggambarkan jalan yang dibuat di sekeliling kolam tersebut terletak di samping lebar kolam. Siswa menggambarkan jalan yang dibuat di sekeliling kolam tersebut terletak di samping lebar kolam renang. Berikut jawaban siswa mencari soal yang ditanyakan:

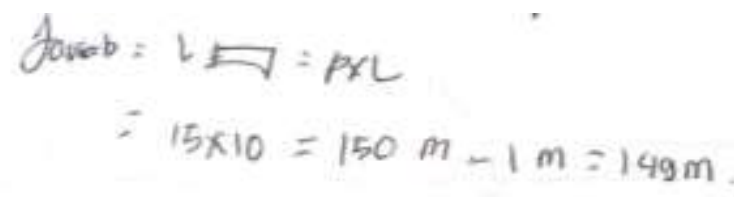

Gambar 5. VSB menuliskan jawaban soal no.2

Pada jawaban di atas, siswa melakukan kesalahan prinsip, karena di awal siswa sudah melakukan kesalahan fakta saat mengubah apa yang diketahui ke gambar, sehingga siswa tidak memahami saat mengerjakan apa yang ditanyakan.
Soal no.3 VSB melakukan kesalahan fakta dan prinsip, namun siswa bisa menuliskan apa yang diketahui dan tujuan permasalahan dari soal. Hal ini dapat dilihat dari lembar jawaban siswa sebagai berikut:

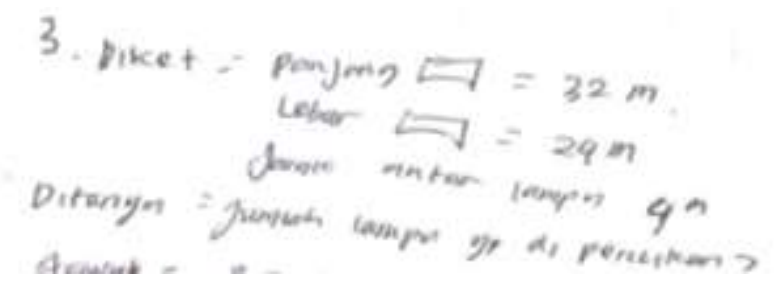

Gambar 6 VSB menuliskan apa yang diketahui dan ditanya dari soal no.3

Hasil wawancara siswa menunjukkan bahwa siswa sudah dapat menyebutkan apa yang diketahui dan ditanya dengan tepat. Berikut hasil wawancara siswa:

$\begin{array}{cc}\text { Peneliti } & \text { : "Dari soal ini bisakah kamu } \\ & \text { menyebutkan apa yang } \\ \text { diketahui dan ditanyakan?" } & \text { : "Bisa, yang diketahui } \\ \text { Siswa } & \text { panjang persegi panjang } \\ & \text { 32m, lebar persegi } \\ & \text { panjang } 24 m \text {, jarak antara } \\ & \text { lampu } 4 m \text {, ditanya jumlah } \\ & \text { lampu yang diperlukan" }\end{array}$

Namun, siswa sebenarnya belum memahami soal secara keseluruhan, siswa masih belum tepat ketika diminta menggambarkan apa yang diketahui. Berikut jawaban siswa ketika diminta untuk menggambarkan apa yang diketahui dan ditanyakan:

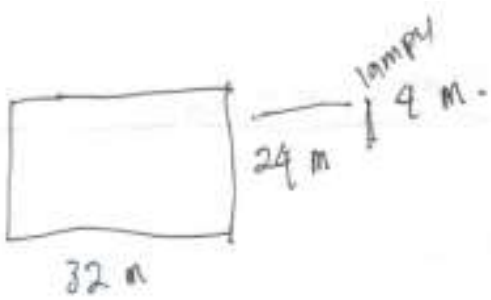

Gambar 7 VSB membuat gambar apa yang diketahui dan ditanya dari soal no.3

Di sini siswa melakukan kesalahan fakta. Siswa masih belum tepat menuliskan apa yang diketahui dan ditanya pada gambar yang dibuatnya. Ketika siswa disuruh menggambarkan apa yang diketahui dan ditanyakan, siswa sudah tepat menggambarkan taman berbentuk persegi panjang 
dengan panjang $32 \mathrm{~m}$ dan lebar $24 m$, namun siswa masih belum memahami lampu yang dipasang di sekeliling taman, siswa menggambarkan lampu yang di pasang itu jaraknya $4 m$ dari lebar. Siswa menggambarkan lampu yang di pasang itu jaraknya $4 m$ dari lebar taman. Berikut jawaban siswa mencari soal yang ditanyakan:

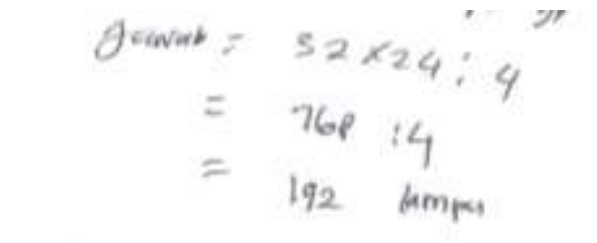

Gambar 8. VSB menuliskan jawaban dari soal no.3

Pada jawaban di atas, siswa melakukan kesalahan prinsip, karena siswa belum memahami secara keseluruhan apa yang ditanyakan. Di awal siswa sudah melakukan kesalahan fakta saat mengubah apa yang diketahui ke gambar, sehingga siswa tidak memahami saat mengerjakan apa yang ditanyakan. Seharusnya siswa menjawab dengan mencari kelilinggnya kemudian dibagikan empat, namun siswa mencari luas taman kemudian dibagi empat.

\section{MA (siswa kemampuan sedang)}

Soal no.1 MA tidak melakukan kesalahan apapun. Berikut hasil jawaban siswa terkait soal no.1:
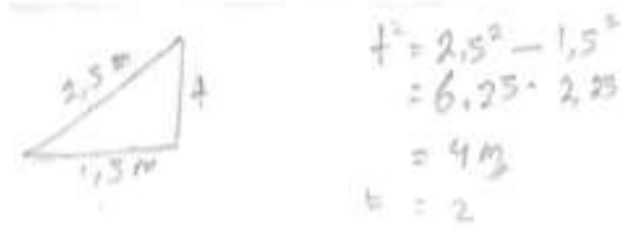

Gambar 9. Hasil jawaban MA dari soal no.1

Siswa sudah tepat menempatkan yang mana tembok, tangga, dan jarak ujung bawah tangga dengan tembok. Ini artinya siswa sudah tepat mengubah apa yang diketahui ke model matematika. Hasil wawancara juga menunjukkan siswa dapat menyebutkan apa yang diketahui dan ditanyakan. Berikut hasil wawancara siswa:
Peneliti
:"Dari soal ini dapatkah kamu menyebutkan apa yang diketahui dan ditanyakan?"
Siswa
: "Dapat, yang diketahui tangga dengan panjang $2,5 m$, jarak ujung

bawah tangga dengan

tembok $1,5 m$, ditanya

tinggi ujung atas tangga

dari lantai"

Soal no.2 MA melakukan kesalahan fakta.

Berikut hasil jawaban siswa terkait soal no.2:

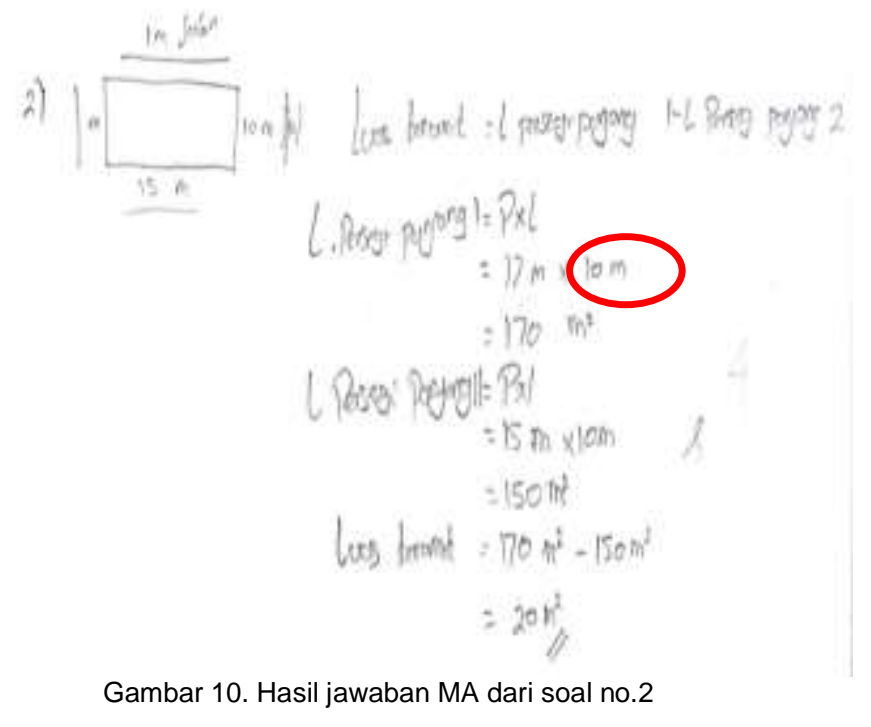

Siswa pada dasarnya sudah bisa memahami soal. Hal ini dapat dilihat ketika siswa sudah tepat menuliskan apa yang diketahui pada gambar yang dibuatnya. Ketika siswa disuruh menjelaskan makna dari gambar yang dibuatnya, siswa sudah menyebutkan apa yang diketahui dan ditanyakan secara tepat. Namun siswa masih kurang jeli menyatakan lebar persegi panjang setelah dibuat jalan keramik di sekeliling kolam. Seharusnya pada lebar persegi panjang yang pertama yaitu $12 \mathrm{~m}$, hasil penjumlahan dari lebar yang diketahui dengan lebar keramik $1 \mathrm{~m}$ dari sisi kiri dan sisi kanan, sehingga menjadi $12 \mathrm{~m}$, tapi siswa menuliskan lebarnya $10 \mathrm{~m}$.

Hal ini didukung oleh hasil wawancara menunjukkan siswa dapat menggambarkan apa yang diketahui dan ditanyakan. Berikut hasil wawancara siswa:

$\begin{array}{cl}\text { Peneliti } & \text { : "Dari soal ini dapatkah } \\ & \text { kamu menyebutkan apa } \\ & \text { yang diketahui dan } \\ & \text { ditanyakan ?" } \\ \text { Siswa } & \text { : "lya, yang diketahui sebuah } \\ & \text { kolam renang berbentuk } \\ & \text { persegi panjang berukuran } \\ & 15 \mathrm{~m} \text {, lebar 10m, dan } \\ & \text { keliling kolam setiap } \\ & \text { sisinya dipasang }\end{array}$


keramik lebar $1 m$, ditanya luas keramik"

Soal no.3 MA melakukan kesalahan prinsip. Berikut hasil jawaban siswa terkait soal no.3:

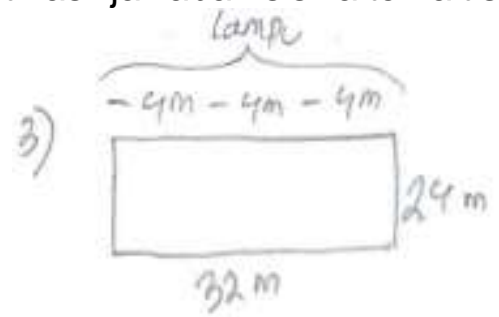

Gambar 11. MA membuat gambar dari apa yang diketahui dari soal no.3

Siswa sudah tepat dan ketika siswa diminta menjelaskan gambar yang dibuatnya dan apa yang diketahui pada gambar yang dibuatnya.. Siswa sudah tepat menggambarkan taman berbentuk persegi panjang dengan panjang $32 \mathrm{~m}$ dan lebar $24 \mathrm{~m}$, dan di sekeliling taman dipasang lampu dengan jarak $4 \mathrm{~m}$. Siswa juga sudah dapat menjelaskan secara tepat gambar yang dibuatnya Siswa sudah tepat menggambarkan di sekeliling taman akan dipasang lampu dengan jarak antar lampu $4 \mathrm{~m}$. Hasil wawancara juga menunjukkan siswa dapat menggambarkan apa yang diketahui dan ditanyakan. Berikut hasil wawancara siswa:

$\begin{array}{cc}\text { Peneliti } & \text { "Dari soal ini bisakah kamu } \\ & \text { menyebutkan apa yang } \\ \text { diketahui dan ditanyakan ?" } & \text { : "Bisa, yang diketahui } \\ \text { Siswa } & \text { sebuah taman berbentuk } \\ & \text { persegi panjang berukuran } \\ & 32 m \text { dan lebar } 24 m \text {, di } \\ & \text { sekeliling taman dipasang } \\ & \text { lampu berjarak } 4 m \text {, ditanya } \\ & \text { jumlah lampu yang } \\ & \text { diperlukan" }\end{array}$

Namun siswa sebenarnya belum memahami apa yang ditanyakan, di sini siswa melakukan kesalahan prinsip. Berikut hasil jawaban siswa:

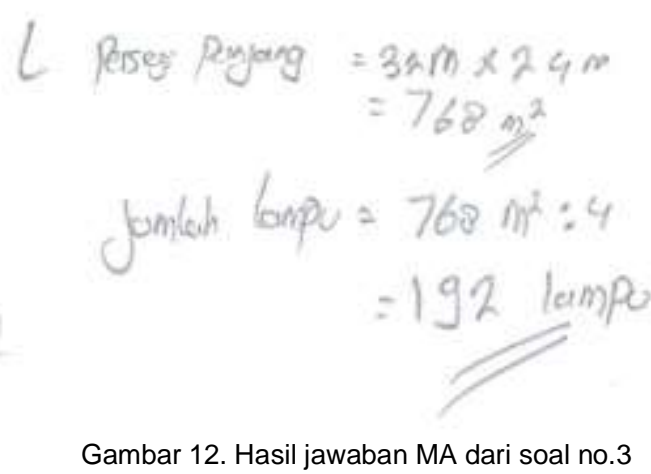

Siswa di sini mencari luas taman kemudian dibagikan empat, seharusnya siswa mencari keliling taman kemudian dibagikan empat. Hal ini membuktikan bahwa siswa memang belum memahami apa yang ditanyakan dengan tepat.

DI (siswa kemampuan tinggi)

Soal no.1 DI tidak melakukan kesalahan apapun. Berikut hasil jawaban siswa terkait soal no.1:
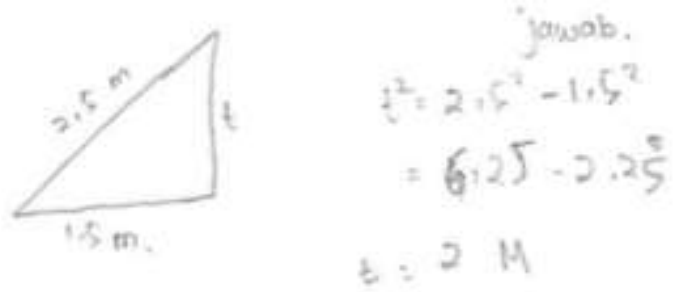

Gambar 13. Hasil jawaban DI dari soal no.1

Siswa sudah tepat menempatkan yang mana tembok, tangga, dan jarak ujung bawah tangga dengan tembok. Ini artinya siswa sudah tepat mengubah apa yang diketahui ke model matematika. Hasil wawancara juga menunjukkan siswa dapat menyebutkan apa yang diketahui dan ditanyakan. Berikut hasil wawancara siswa:

Hasil wawancara juga menunjukkan siswa dapat menggambarkan apa yang diketahui dan ditanyakan. Berikut hasil wawancara siswa:

$\begin{array}{cl}\text { Peneliti } & \text { : "Dari soal ini dapatkah } \\ & \text { kamu menyebutkan apa } \\ & \text { yang diketahui dan } \\ & \text { ditanyakan ?" } \\ \text { Siswa } & \text { : "Dapat, yang diketahui } \\ & \text { panjang sebuah tangga } \\ & 2,5 \mathrm{~m} \text {, tembok ujung }\end{array}$


bawah tangga $1,5 m$, ditanya tinggi ujung atas tangga dari lantai"

Soal no.2 DI melakukan kesalahan fakta dan kesalahan prinsip. Berikut hasil jawaban siswa terkait soal no.2 :

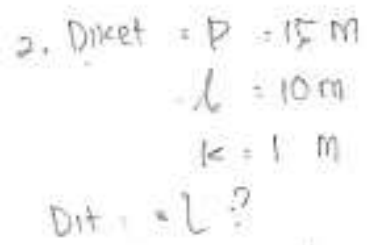

Gambar 14. DI menuliskan apa yang diketahui dan ditanya dari soal no.2

Di sini siswa melakukan kesalahan fakta, siswa masih kurang teliti. Hal ini dapat dilihat ketika siswa belum tepat menuliskan apa yang diketahui dan ditanyakan. Siswa sudah tepat menuliskan panjang kolam renang $15 \mathrm{~m}$ dan lebar kolam renang $10 \mathrm{~m}$, namun siswa menuliskan keliling $1 \mathrm{~m}$, padahal yang dimaksud $1 \mathrm{~m}$ tersebut yaitu lebar keramik di keliling kolam setiap sisinya. Padahal ketika diwawancarai siswa sudah tepat menyebutkan apa yang diketahui dan ditanyakan. Berikut hasil wawancara siswa:

Peneliti : "Dari soal ini bisakah kamu
menyebutkan apa yang
diketahui dan ditanyakan?"

Siswa

: "Bisa, yang diketahui sebuah kolam renang berbentuk persegi panjang berukuran $15 \mathrm{~m}$, lebar $10 \mathrm{~m}$, dan keliling kolam setiap sisinya dipasang keramik lebar $1 \mathrm{~m}$, ditanya luas keramik"

Ketika diminta menggambarkan, siswa juga belum tepat menggambarkan apa yang diketahui. Di sini siswa juga melakukan kesalahan fakta.

Berikut jawaban siswa:

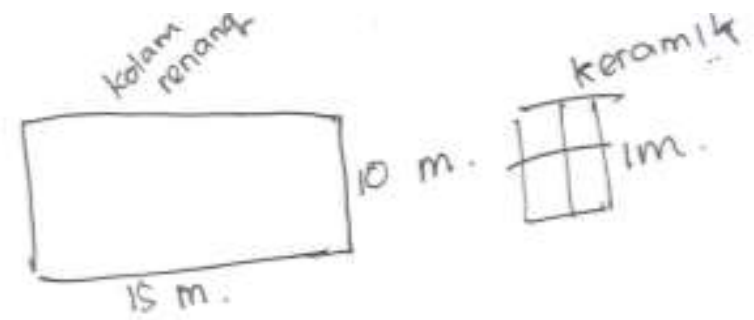

Gambar 15. DI membuat gambar dari apa yang diketahui dari soal no.2
Siswa menggambarkan keramik di sekeliling kolam hanya di sisi kanan kolam saja, seharusnya keramik $1 \mathrm{~m}$ itu berada di sekeliling kolam. Karena siswa sudah salah memahami soal sehingga ketika menjawab soal juga tidak tepat, siswa melakukan kesalahan prinsip. Berikut jawaban siswa:

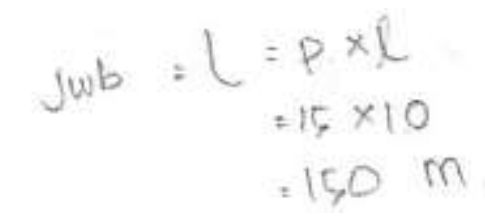

Gambar 16. Hasil jawaban DI dari soal no.2.

Siswa masih belum tepat menjawab apa yang ditanyakan dari soal. Siswa hanya mencari luas kolam renang saja. Seharusnya siswa mencari luas kolam setelah dipasang keramik dengan lebar $1 \mathrm{~m}$ juga, kemudian dikurangkan dengan luas kolam renang.

Soal no.3 DI melakukan kesalahan fakta. Berikut hasil jawaban siswa terkait soal no.3:

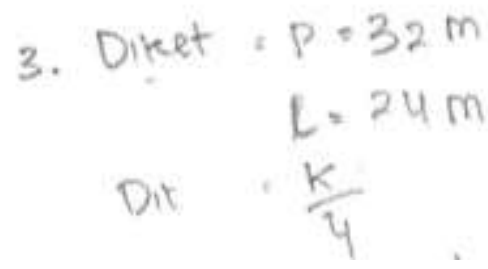

Gambar 17. DI menuliskan apa yang diketahui dan ditanya dari soal no.3

Di sini siswa sudah tepat menuliskan apa yang diketahui dan daitanyakan. Hal ini dapat dilihat ketika siswa sudah dapat menuliskan apa yang diketahui dan ditanyakan pada soal dengan tepat. Siswa sudah tepat menuliskan panjang $32 \mathrm{~m}$ dan lebar $24 m$ serta paham maksud dari jumlah lampu yang ditanyakan dengan menuliskan $\frac{k}{4}$. Hasil wawancara siswa juga menunjukkan bahwa siswa sudah dapat menyebutkan apa yang diketahui dan ditanya dengan tepat. Berikut hasil wawancara siswa:
Peneliti : "Dari soal ini dapatkah
kamu menyebutkan apa yang
diketahui dan
ditanyakan ?"
Siswa : "Dapat, yang diketahui panjang $32 m$ dan lebarnya $24 m$, di sekeliling 
taman dipasang lampu

berjarak $4 m$, ditanya

jumlah lampu yang

diperlukan"

Namun ketika siswa diminta menggambarkan apa yang diketahui, siswa masih belum tepat. Berikut jawaban siswa:

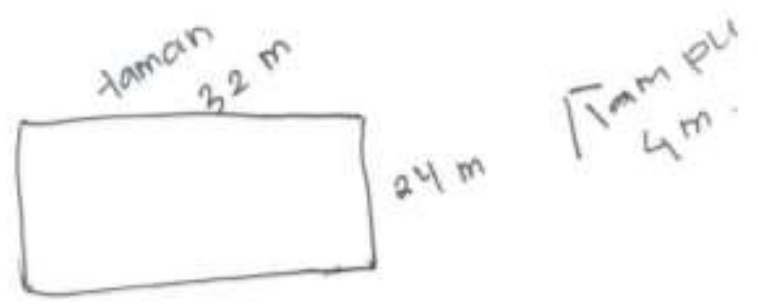

Gambar 18 DI membuat gambar dari apa yang diketahui dari soal no.3

Siswa menuliskan lampu yang dipasang di sekeliling taman dengan jarak $4 \mathrm{~m}$, siswa menuliskan di samping taman. Di sini siswa melakukan kesalahan fakta. Namun ketika menjawab soal, siswa sudah tepat. Berikut jawaban siswa :

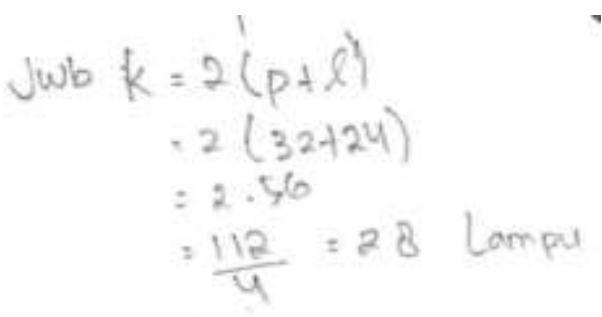

Gambar 19 Hasil jawaban DI dari soal no.3

Siswa sudah tepat menggambarkan taman berbentuk persegi panjang dengan panjang $32 \mathrm{~m}$ dan lebar $24 m$, namun siswa masih belum tepat menggambarkan lampu yang dipasang di sekeliling taman, siswa menggambarkan lampu yang di pasang itu jaraknya $4 m$ dari lebar taman. Siswa sudah bisa menyelesaikan permasalahan yang ada, tapi belum tepat menerjemahkan apa yang diketahui ke gambar yang dibuatnya.

\section{KESIMPULAN}

Hasil penelitian ini menunjukkan siswa masih kesulitan dalam mengerjakan soal cerita. Siswa kemampuan rendah melakukan kesalahan fakta pada soal no.1, kesalahan fakta dan prinsip pada no.2, serta kesalahan fakta dan prinsip pada soal no.3. Siswa kemampuan sedang melakukan kesalahan fakta pada soal no.2 dan kesalahan prinsip pada soal no.3. Siswa kemampuan tinggi melakukan kesalahan fakta dan prinsip pada soal no.2 serta kesalahan fakta pada soal no.3. Namun ketiga siswa tidak melakukan dua kesalahan lainnya, yaitu kesalahan operasi dan konsep. Hal ini menunjukkan ketiga siswa ini sudah bagus dalam hal melakukan operasi matematika dan konsep matematikanya.

\section{DAFTAR PUSTAKA}

Adinawan, M., Cholik \& Sugijono. (2008). Seribu Pena Matematika untuk SMP/MTs Kelas VII. Intisari Materi Contoh Soal \& Pembahasan Uji Kompetensi. Jakarta: Erlangga.

Alfiyah. (2011). Meningkatkan hasil belajar soal cerita materi segiempat melalui penerapan teknik analisis kesalahan Newman bagi siswa kelas 7 SMPN 1 Sukodono Lumajang (RSBI). Tesis: Universitas Negeri Malang, Program Studi Pendidikan Matematika

Cooney,T.J.,Davis,E.V.\&,Henderson,K.B. (1975).

Dinamics of Teaching Secondary School

Mathematics. Boston: Houghton Mifflin

Company.

Fatmawati, H., Mardiyana, \& Triyanto. (2014). Analisis berpikir kritis siswa dalam pemecahan masalah matematika berdasarkan polya pada pokok bahasan persamaan kuadrat. Jurnal Elektronik Pembelajaran Matematika, 2(9).

Gangga, Ubayu Wahyuning Awi. 2013. Analisis Kesulitan Belajar Peserta didik pada Topik Limit Fungsi Aljabar dan Pemecahannya. Universitas Sebelas Maret: Surakarta.

Herlambang. (2013). Analisis kemampuan pemecahan masalah matematika siswa kelas VII-A SMP negeri 1 Kepahiang tentang bangun datar ditinjau dari teori van hiele. Tesis Program Studi Pascasarjana (S2) Pendidikan Matematika Fakultas Keguruan dan IImu Pendidikan. Universitas Bengkulu.

Ifanali. (2013). Penerapan langkah-langkah polya untuk meningkatkan kemampuan pemecahan masalah soal cerita pecahan pada siswa kelas VII SMP negeri 13 Palu. Jurnal Elektronik Pendidikan Matematika Tadulako, 1(2).

Musriniyatik, A. S \& Sutanto, H. (2014). Pembelajaran melalui metode penemuan terbimbing untuk memahamkan siswa kelas VIII E SMP Negeri 1 Lamongan pada Materi 
Lingkaran. Prosiding Seminar Nasional TEQIP (Teachers Quality Improvement Program) dengan tema "Membangun Karakter Bangsa melalui Pembelajaran Bermakna TEQIP. Universitas Negeri Malang.

Ozerem, A. (2012). Misconceptions in geometry and suggested solutions for seventh grade students. International Journal of New Trends in Arts, Sports \& Science Education, 1(4).

Purwanto, M. \& Suroto. (2014). Analisis kesalahan siswa dalam menyelesaikan masalah matematika bentuk soal cerita pada pokok bahasan peluang SMA thribakti tanggulangin kelas XII IPS. Jurnal Pendidikan atematika STKIP PGRI Sidoarjo, 2(1).

Rahardjo, M. \& Waluyati, A. (2011). Pembelajaran soal cerita operasi hitung campuran di sekolah dasar (modul matematika SD dan
SMP program BERMUTU). Yogyakarta: PPPPTK Matematika.

Roskawati, Ikhsan, M., \& Juandi, D. (2015). Analisis penguasaan siswa sekolah menengah atas pada materi geometri. Jurnal Didaktik Matematika, 1(2).

Rudtin, N. A. (2013). Penerapan langkah Polya dalam model problem based instruction untuk meningkatkan kemampuan siswa menyelesaikan soal cerita persegi panjang. Jurnal Elektronik Pendidikan Matematika Tadulako, 1(1).

Sukayasa. (2009). Penalaran dan pemecahan masalah dalam pembelajaran geometri. Prosiding Seminar Nasional Penelitian, Pendidikan dan Penerapan MIPA, Fakultas MIPA, Universitas Negeri Yogyakarta. 